Article

\title{
The Fullness of Time: Kierkegaardian Themes in Dreyer's Ordet
}

\author{
Daniel Watts
}

School of Philosophy and Art History, University of Essex, Colchester CO4 3SQ, UK; dpwatts@essex.ac.uk

Received: 20 December 2018; Accepted: 14 January 2019; Published: 17 January 2019

\begin{abstract}
I offer an approach to Dreyer's film Ordet as a contribution to the phenomenology of a certain kind of religious experience. The experience in question is one of a moment that disrupts the chronological flow of time and that, in the lived experience of it, is charged with eternal significance. I propose that the notoriously divisive ending of Ordet reflects an aim to provide the film's viewers with an experience of this very sort. I draw throughout on some central ideas in Kierkegaard's work, especially his category of 'the moment.'
\end{abstract}

Keywords: philosophy; Kierkegaard; Dreyer; religion; phenomenology; spirituality; film; eternity; time; temporality

At the center of Carl Theodor Dreyer's Ordet [The Word] (1955) is a man named Johannes. For the greater part of the duration of the film, Johannes is apparently insane and incapable of distinguishing himself from Jesus Christ. In an exchange that is probably as close as the film comes to making a joke, a priest asks one of Johannes' brothers what caused his madness:

PRIEST: Was it-love?

MIKKEL: No, no, it was Søren Kierkegaard.

The Priest is the face of institutional Christianity in the film. He turns out to be suspiciously aligned with the secularist medical doctor. For his part, Johannes' namesakes include St. John and, together with the film's title, his name no doubt contains an allusion to John 1: 'In the beginning was the Word ... And the Word became flesh'. We might also hear in this name an echo of the 'Johannes' to whom Kierkegaard attributed authorship of his most famous book, Fear and Trembling. This fictional author's full name-Johannes 'de Silentio', John the Silent—already suggests a problematic relationship to his own words and this is certainly true of the Johannes in Ordet. Based on a play by the Danish pastor Kaj Munk, this is at any rate a film in which Kierkegaard is quite clearly in the background. ${ }^{1}$

In this essay, I propose to treat Ordet as a contribution to the phenomenology of a distinctive kind of religious experience. The experience in question is one of a moment that disrupts the chronological flow of time and, that, in the lived experience of it, is charged with eternal significance. I shall draw throughout on some central ideas in Kierkegaard's work, especially his category of 'the moment.' I hope to bring into mutual illumination Dreyer's magisterial film and some difficult but important ideas in Kierkegaard.

I shall begin (in Section 1) with an overview of the conflict the film portrays between two rival visions of religious life within Christianity. My aim here is to draw out the way in which a certain dilemma between competing religious perspectives on time and eternity, and corresponding ways

1 According to Sverre Arestad, 'Munk early came under the influence of Kierkegaard' who became his 'spiritual father' (Arestad 1954, p. 157). 
of responding to times of crisis, is integral to the film's dramatic structure. It is also part of this aim to bring out the centrality in the film not only of Johannes but also of Inger, Johannes' sister-in-law, as one who points a way beyond this dilemma. I shall then (in Section 2) turn to the way in which time itself is represented in the film and draw on some of Kierkegaard's ideas to help interpret how Ordet represents the possibility of a certain kind of disruption to our everyday experience of time. I will show how, under the category of 'the moment,' Kierkegaard thinks through this type of human of experience of time, using both secular and religious illustrations. In the religious context, we shall see how he presents it as just such an experience of disruption in our ordinary experience of time that is foundational for Christian faith: an experience of the historical moment of Jesus of Nazareth as a moment of 'the fullness of time.' Finally, in Section 3, I will take up the proposal that Ordet not only represents such moments of disruption to our everyday experience of time but seeks to provide for its viewers an experience of this very kind, through its utterly arresting dénouement. Since it is difficult to see how a film could elicit an experience of the fullness of time, I will explore this proposal with the help of an analogy with some claims Kierkegaard makes about the temporality of an evening at the theater. My aim throughout is not merely to show how Ordet illustrates certain philosophical ideas but to bring Kierkegaard's thought into dialogue with Dreyer's film.

\section{Inger after Borgen and Peterson}

Ordet is a drama of times of crisis: crises in the personal lives of its protagonists and crises in the communal forms of life in which they are embedded, not least in their received forms of religious life. Central to its narrative is the way the film portrays modern religious life as caught between the horns of a dilemma, embodied by the stand-off between the two patriarchs, Morten Borgen, one of whose sons is the unorthodox Johannes, and Peter Peterson the tailor, whose daughter Borgen's youngest son wants to marry. On the one side of the dilemma is a this-worldly, practical, instrumentalist approach to religion, embodied by old Borgen's Grudtvigian version of Christianity. Here, as we might put it, the value of religion is to be measured by its real-world 'impact' — and, as some of Borgen's remarks seem to betray, is especially to be prized as a means of maintaining social-economic privilege. On the other side, we have an other-worldly, life-renouncing, religiosity, in which everydayness is the enemy. This second horn of the dilemma is memorably encapsulated in the film by a meeting of the Inner Mission, the stern revivalist denomination in which the notably less wealthy Peterson plays a leading role. In this scenario, religious life seems aptly figured by the caged bird, which is about the only decorative item in the Peterson's house: religion as the impulse to escape this cage of embodied temporal existence.

The following account, from a social history of Danish religious life, helps to set the scene of this collision between world-affirming and world-denying strains of Christianity:

With the introduction of the new national constitution in 1849, religion in Denmark changed rapidly. The state's monopoly over religious expression disappeared, swept away by enlightenment philosophy that had undermined the monarchy and transformed rural society ... Clergy split into several camps, called Church Movements, which became bitterly opposed to one another over the next half century ... [principally] between the folk-life oriented Grundtvigians and the pietist Inner Mission ... Grundtvig's celebration of folk culture inspired a myriad of secular organizations, mostly aimed at raising the consciousness and living standards of rural society ... . The Mission's most marked feature was the sharp distinction it drew between its followers, "God's children," and "the children of the world." ... [It] urged converts to renounce the pleasures, fashions, and company of the sinful world from which the mission had saved them. The "holy ones" dressed in simple and severe clothing. They abstained from liquor, tobacco, card playing, dancing, and the theater. They studiously avoided any political involvement and, above all, they shunned social contact with the unconverted ... The holy must keep their thoughts on heaven, not on the sinful and ephemeral world from which they came. (Buckser 1993, pp. 133-34) 
As representatives of these two competing strains within Christianity, Borgen and Peterson are able to exemplify two strongly contrasting types of religious responses to times of crisis in general: the turn to religion (and especially to prayer) either as a means of trying in an uncertain world to secure various temporal ends-or as a way of protecting oneself from disappointment by eschewing all finite ends as worldly, trying to leap right out of time, as it were, and into eternity. We might even say these two forms of religious life represent rival strategies of 'crisis-management.'

Now, even more than Johannes, the pivotal figure of Ordet is in many ways Inger, the wife to the unbelieving Mikkel. ${ }^{2}$ The antagonism between Ordet's two patriarchs, and between their rival visions of Christian life, is brought to a head, à la Romeo and Juliet, through the prospect of a union between their offspring, Anders and Anne. However, their relationship takes a radically new turn when the two families are together confronted by the crisis that animates the film's climactic moments: when Inger suffers a miscarriage and dies. In a scene around Inger's open coffin, Borgen and Peterson have both evidently lost their religious self-confidence. Peterson has arrived at Borgenstead after finding himself unable to attend church, painfully aware of the offense he has caused to Borgen. For his part, Borgen has no reply to Mikkel's bitter sarcasm about the requisite religious accoutrements of the funeral. Moreover, as viewers of the film, we are invited into a perspective in which both of the religious orientations represented by the old men are revealed as hollow and moribund, impotent in the face of Inger's death. Having for some time mysteriously gone missing, and meanwhile having apparently come to his senses, Johannes also returns. Speaking at first with Borgen, who receives his son as one who has now recovered his reason and again sees clearly, and with the Priest also present, Johannes approaches the coffin:

JOHANNES: Not one of you has thought of asking God to return Inger to you.

BORGEN: Johannes, now you mock God.

JOHANNES: No, all of you mock God with your half-heartedness ... Why, among all the believers, is there no one who believes? Inger, you must rot because the times are rotten.

Johannes' question-why, among the believers, there is no one who believes-has the hallmarks of irony. It echoes Socrates' question about his fellow Athenians: among all the wise, are there any wise ${ }^{3}$ Still more directly, it echoes Kierkegaard's self-consciously Socratic question about the Danish Christendom of his own day: among all the Christians, are there any Christians? ${ }^{4}$ Across denominations, the forms of religious life exhibited by those to whom Johannes addresses his ironical question are exposed by it as tepid, shallow, and lifeless. In the terms of Jonathan Lear's account of existential irony, Inger's death exposes a chasm between the pretense of faith, as embodied in the received practices and institutions of religion, and the aspirations implicit in this pretense. ${ }^{5}$

However, it is not for Inger to rot. In the film's wondrous finale, Johannes is inspired by the simple trust in him shown by Inger's daughter to do what the Priest can only regard as madness: in the name of Jesus, to ask God to return Inger to them. Part of what is unforgettable about the apparent miracle that follows is Inger's sheer bodily presence: in Ordet's final scene, now risen indeed, the tearful Inger, in close-up shot, sensuously kisses Mikkel on his face and passionately repeats the word, 'liv' ['life'].

I shall return below to the question of what we are to make of Ordet's confounding ending. However, what should already be clear is that Inger's apparent death and resurrection is the focal

2 Notably, the small existing literature on Kierkegaard and Dreyer tends to focus on Johannes, as a symbol of the Kierkegaardian faith that must look like madness. See e.g., (Ziolkowski 2011). This focus is natural enough, given the link made within the film itself between Johannes and Kierkegaard. As I shall argue, however, the Kierkegaardian themes in Ordet more fully coalesce around the figure of Inger.

3 See Plato's Apology, 20d ff.

4 In several works of self-commentary, Kierkegaard present his ironical interrogation of Christendom as a unifying theme of his writings in general (see Kierkegaard 1998).

5 See (Lear 2014). 
point of a radical crisis in the religious lives of both Borgen and Peterson. While mourning Inger, Borgen could only manage a limply pious phrase to the Priest to the effect that God must have some good purpose in allowing her to die (the Priest's response is the counterpoint to Johannes' ironical question: 'spoken like a true believer'). Yet now, as a witness to the miracle, he trembles in agreement with Peterson: 'He is still the God of old, the God of Elijah, eternal and the same.'

There is something of a paradox here. On the one hand, their wonder at the miracle seems to cut across the differences between Borgen's and Peterson's characteristic religious orientations: instrumental, and other-worldly. On the other hand, their newfound understanding of the eternal is associated above all with the very bodily resurrection of Inger, whose sensuality is underlined in the film's final scene. The impression of paradox here arises to the extent that we find it natural to regard the bodily and the sensual as standing in tension with the religious as such (as we will to a large extent if we associate the religious as such with certain kinds of asceticism). In fact, in this regard, Inger presents a foil to the old men throughout the film. The contrast with Borgen is nicely encapsulated by a homely scene early on in which Inger, having prepared the coffee and biscuits, is sitting at a table looking heavenward, unaware that her father-in-law has entered the room:

INGER: Dear God, please help me today also.

BORGEN: It's because the rain has been coming through the roof.

INGER: Oh it's you, Grandfather? You gave me quite a fright.

BORGEN: I did what?

INGER: What were you saying?

BORGEN: I said the damp patch up there was rainwater. The roof's leaking.

INGER: Well I never-so it is.

While Inger transfigures her everyday tasks with a simple act of prayer, Borgen can only see dampness in the roof. However, the comparison with Inger brings into relief a feature that is common to both the patriarchs' forms of religiousness. Broadly speaking, this is their inability to see the eternal in the finite, the spiritual in the bodily, and the transcendent in the everyday. By contrast, Inger seems to embody something of the ideal of which William Blake sings:

To see a World in a grain of sand, and a Heaven in a wild flower, Hold Infinity in the palm of your hand, and Eternity in an hour. (Blake 2008, p. 490)

As Inger says herself, addressing Borgen in a moment of religious doubt: 'Well, I think that many tiny miracles occur all around us.' Notably, Inger is the one who takes on the task of gently mediating between the two families on behalf of Anders and Anne. Notably, too, it is Inger who, from the outset, lovingly mediates between Johannes and Mikkel, holding out hope for both: that Johannes will return to himself and that Mikkel's good heart will eventually lead him to faith. Together with the film's finale, what all this seems to indicate is that, through Inger-and through her lived faith, hope, and love-time is somehow touched by the eternal.

We have observed how, in a general way, Johannes clearly echoes Kierkegaard's ironical interrogation of Danish Christendom. We may add that it is, in fact, already part of Kierkegaard's own ironical standpoint to oppose those very tendencies within Christendom that we find portrayed by the old men in Ordet. Himself a contemporary of Grundtvig's, Kierkegaard expressly dismissed the Grundtvigians' nationalist-romantic ideology as 'twaddle', lampooning the man himself as an incoherent muddle: 'a noisy individual, godly, worldly, Old Norse, Christian, high priest, Holger the Dane' (Cited in Garff 2000, p. 322; Kierkegaard 1992, vol. II, p. 26). Regarding those he sometimes calls 'the superorthodox', or religious 'enthusiasts,' on the other hand, Kierkegaard recommends that 
we hand over to the irony of the 'arrogating revivalist' who congratulates himself for having given up on life and the 'hard road of ... knowledge and thinking' in order to 'leap aside and become absolutely revived' (Kierkegaard 1992, vol. I, p. 564). (This recommendation is especially notable given that Kierkegaard himself is still all too often associated with just such misology and just such a leap.) More positively, Kierkegaard expressed a desire to find out how to practice Christianity 'here in Copenhagen, in Amager Square, in the everyday hustle and bustle of weekday life' (Kierkegaard 1991, p. 59 (translation modified in Pattison 2002, p. 23)).

Against this Kierkegaardian background, the significance of the figure of Inger within Ordet stands out all the more strikingly. For, as we have begun to see, to the extent that she is believable, Inger holds out the prospect of an alternative to the Borgen/Peterson antithesis: a gentle, reticent form of religiousness in which even 'the everyday hustle and bustle of weekday life' is shot through with eternal significance. In this, we might see her not only as a Kierkegaardian exemplar but, on a grander scale, as representing the prospects for the survival of religious life in Western modernity, as even the more this-worldly traces of Christendom are overtaken by ever more thoroughgoing processes of secularization. ${ }^{6}$ However, the film's most extreme moment of tension and crisis is not one to which it seems Inger is in any sort of position to respond: for this is, of course, the moment of her death. How in general, then, are we to understand the dénouement of the film in which Johannes is restored to sanity and, apparently through his prayerful faith, Inger to life? Moreover, how are we to understand this finale, against the background of the film's overall presentation of Inger as one who somehow mediates the temporal and the eternal?

Let me approach these questions obliquely, by drawing out some further Kierkegaardian themes from the ways in which time itself shows up in Dreyer's film.

\section{Inger after Ingeborg}

While it would go too far to say that time is personified in Ordet, this is certainly a film in which time looms large. For one thing, a wall clock with a pendulum plays a prominent visual and aural role. More generally, its rhythm and tempo are especially marked in the experience of watching this film and, for much of it, markedly slow. (In his writings on film, Dreyer himself highlights the importance of rhythm and tempo: 'characteristic of all good film', he writes, 'is a certain rhythm-bound restlessness' (cited in Rosenbaum 2010, p. 234).) In one scene, Borgen complains of the Priest that 'it takes him too long to get to the amen' - a remark which, as the critics have sardonically noticed, anticipates and parodies what most viewers leaving the theater will say about Dreyer and his film. This slow tempo is no doubt partly a function of the extensive use of the long take. It has been calculated that, within the three central sections of the film, the average shot lasts over a minute and a half (Bordwell 1981, p. 151). Together with the film's minimal use of close-ups, the sparse décor of the rooms and the noticeable arc-and-pan movement of the camera, these long takes serve clearly to register temporal duration in our experience of watching the film.

What is really striking about Ordet in this regard, however, is the way in which time seems within it to gather itself up, as it were, to a climactic moment. ${ }^{7}$ In the terms in which the Gospel narrators build up to their accounts of Christ's death and resurrection, this is a moment of kairos, that is, a moment when time itself becomes ripe. This kairological effect is intensified by prophetic moments throughout the film, which disrupt the linear chronology such as the page we glimpse of an illustrated Bible depicting the resurrection of Lazarus.

If Ordet is about times of crisis, then, it also makes thematic the human experience of time as such. We may further note here a connection between the very idea of a crisis and a certain way of

6 Where Johannes noisily confuses himself with Christ, Inger is perhaps Mary-like in her quietude and sacrificial love. On Kierkegaard on male and female exemplars of faith, and with reference to Mary, see (Carlisle 2016).

7 Compare in this regard the effect achieved in Robert Bresson's film, A Man Escaped. 
experiencing time. The etymology gives the clue: 'crisis', from the Greek krinein, 'to separate, decide, judge', the word was used in a medical context-by Hippocrates and Galen, for example—to refer to a turning point in the duration of a disease. We might, therefore, expect Ordet to be especially attuned to a certain sort of human experience of time: namely, the experience of a temporal threshold, a parting of the ways, a watershed moment. In addition, at a moment of extreme crisis toward the end of the film, the wall-clock literally stops-and then later seems to be started again (upon closer inspection, it seems the stopped clock is mysteriously replaced by another clock).

Now, the notion of a temporal threshold is central also to Kierkegaard's category of 'the moment.' Consider one of his illustrations:

When Ingeborg looks out over the sea after Frithiof, this is a picture of what is expressed in the figurative word [sc. the Danish word, 'Øjeblik', 'moment']. (Kierkegaard 1981, p. 87)

This illustration alludes to a particular moment of crisis in Frithiof's Saga. Ingeborg is looking out to sea after her lover, who has been sent away from her, knowing she will never again see him. In this moment, pregnant with lost love and a long-anticipated future now forever closed off, time, as we say, 'stands still.' Ingeborg stands there, gazing out at the empty sea, mutely transfixed, frozen in the moment. Here, we have a moment of existential crisis, a temporal threshold, a parting of the ways, experienced as such. Kierkegaard's thought is that Ingeborg's gaze is a picture of what might also be expressed by the metaphor that is built into the very word in Danish for 'moment', Øjeblik, literally 'glance of the eye.'

As the specificity of his illustration already indicates, Kierkegaard thinks this way of experiencing time, as a temporal threshold, is far from run-of-the-mill. On the contrary, it is one in which our typical human experience of the smooth flow of time is disrupted. Quite generally, human beings are, in Kierkegaard's terms, 'dialectical with respect to time' (Kierkegaard 1985, p. 79). This means: our relationship to time is not merely that we exist in it, as numerically distinct objects among objects in the space-time continuum, but how we exist is also shaped in complex ways by our more or less explicit awareness of time..$^{8}$ Accordingly, Kierkegaard's work offers inter alia phenomenological studies of how our human experience of time can be variously modified. Thus, for example, his work investigates possible structures of human temporality in which subjects come no longer to regard the future as a field of open possibilities, whether because they relate to the future as though it were already past or because they relate to the past as though it were wholly determinative for the future. ${ }^{9}$ In this general approach to the phenomenology of time, the human experience of time is not uniform and universal but, to borrow some terminology from Galen Strawson, allows for different 'temporal temperaments,' which are variable both across subjects and across individuals' lifetimes. ${ }^{10}$

Nonetheless, Kierkegaard also supposes that, in our humanly typical experience of it, time continually passes from an open future into the past, as indicated by the images that come most naturally to us in this connection: the metaphor of time's arrow, for instance, or of the ceaseless 'flow' of time. In this default mode, we do not experience any present moment as such. On the contrary, to the extent that we experience a sequence of 'now's, these are experienced as 'infinitely vanishing', continually rushing into the past. In fact, Kierkegaard maintains that, in our typical experience of time, we never truly experience a pure 'now', a temporal present. He thinks we really relate to the present only via the past as we experience the past as what was once present, 'just now'. 'The present,

8 Compare these striking formulations from Borges: 'Time is the substance I am made of. Time is a river which sweeps me along, but I am the river; it is a tiger which destroys me, but I am the tiger; it is a fire which consumes me, but I am the fire' (Borges 2007, p. 229).

9 See, for example, Kierkegaard's portrayal of 'the unhappiest one' as the one who hopes for his past (Kierkegaard 1987, p. 225ff) or his description of the temporality of certain addictive behaviors in terms of a 'presentiment of the prostration of freedom that is reserved for the next moment' (Kierkegaard 1981, p. 116).

10 See (Strawson 2004). In this regard, Kierkegaard's work anticipates recent phenomenological approaches to the distinctive forms of human temporality associated with, for example, clinical depression. See e.g., (Owen et al. 2015). 
the moment, is over so quickly', he observes elsewhere, 'that it actually does not exist. It is only the boundary and, therefore, is past, whereas the past is what was present.' (Kierkegaard 1995, p. 249).

It is against this background of the incessant, ever-elusive flow of time that crisis-moments like Ingeborg's stand out. In such experiences, we encounter moments of time in a different mode: not as what infinitely slips through out fingers as it vanishes into the past but as phenomenally manifest in a particular way. From the perspective of such an experience, the clock stops. This is not to say that 'the moment' is ever directly and explicitly manifest, even in times of crisis. For Kierkegaard, on the contrary, this is part of the aptness of the image of the glance of the eye, where what is being described is a kind of implicit and inarticulate awareness of a temporal threshold. ${ }^{11}$ Ingeborg is not looking directly at time itself. Nor is she having occurrent thoughts about time. She is gazing out to sea. However, ex hypothesi, her gaze is structured by her implicit awareness of the significance of this moment as a temporal threshold. In Heidegger's terms, the moment is a phenomenon 'in the phenomenological sense' rather than 'in the ordinary sense': that is, it is not an appearance itself, the phenomenal content of an experience, but rather a way in which things can manifest themselves to us (Heidegger 1962, p. 57).

Can we say anything more about how things manifest themselves to us when they manifest a temporal threshold? One of the further ways in which Kierkegaard describes this phenomenon is in terms of an intersection between time and eternity. Of course, he does not mean to deny that any given experience of 'the moment' has a limited duration. His claim is phenomenological: within our lived experience of it, 'the moment' grants us an eternal perspective. Consider again the case of Ingeborg. In what sense does time 'stand still' for her as she gazes out to sea? How is her crisis-moment phenomenally present to her? Plausibly, the sense in which time stands still for her is the sense in which she experiences her whole life-trajectory as changed by this decisive moment. It is in just this sense that she is given an eternal perspective through her experience of a temporal threshold charged with existential significance: that is, the perspective in which she takes in, as it were at a glance, the whole trajectory that leads up to this temporal watershed and then, from it, into the future.

We reach, at this point, one of the most puzzling aspects of Kierkegaard's treatment of 'the moment.' From what we have said so far, it would be natural to suppose that he conceives of 'the moment' as a special way in which we encounter the present: not, to be sure, in the typical mode of a series of infinitely vanishing moments, as what was always 'just now,' but instead as a temporal threshold. In fact, as we have just observed, Kierkegaard thinks that what it means to experience something as a temporal threshold involves all three modes of what MacTaggart famously labelled, 'the A series' (McTaggart 1908). That is, this type of experience is structured by an awareness of the past trajectory leading up to a present tipping point and then from it into the future. Yet, there is more. For Kierkegaard, it is, in fact, an awareness of the future that is primary in this kind of experience. Here is a way to understand his thinking. Consider in what way Ingeborg could be said to be aware of the present as she gazes out to sea. We could say that she is aware of the present as a temporal threshold. However, we should be clear that all this really means is that she is aware of a watershed or boundary between the past and the future. Having noticed this, however, we should further register an important asymmetry between the past and the future in this type of experience. Ingeborg does not primarily experience the past as such. As she gazes out to sea, she is not, for example, merely fondly remembering good times with her beloved. Rather, she experiences the past as leading up to a point which forever closes off her future with Frithiof. It is the newly disclosed future that is really primary in this type of experience.

As many of Kierkegaard's other writings attest, and as we have already begun to trace, the idea of a moment in which eternity touches time, and which, therefore, has an essentially future-oriented

11 As George Pattison puts it, '[I]n the instant she [sc. Ingeborg] expresses her feelings in a sigh or a word 'the moment of vision' in a strong sense is essentially past, because a sigh or a word would be an attempt to articulate what she feels within the relativistic web of language and temporally determined communication' (Pattison 2002, p. 18) 
character, is central to certain forms of religious life. ${ }^{12}$ In fact, Kierkegaard associates this idea quite specifically with Christianity, the religion of the incarnation. From this perspective, while other religions describe gods who take on human form and posit human beings who are divinely inspired, what is utterly distinctive about Christianity is the doctrine that God has become human so that, at a particular moment of history, there lived for a number of years a human being who was very God ('the Word'). Thus, in the writings attributed by Kierkegaard to another fictional Johannes-Johannes Climacus-'the moment' is associated with this teaching, that a person's eternal felicity turns on how he or she relates to reports of a certain historical event, namely, the life of Jesus of Nazareth. For Climacus, the contrast is with any teaching in which a given period of time could never be of greater significance than as a mere occasion for religious or philosophical enlightenment and in which the eternal (if 'the eternal' is invoked at all) is thoroughly divorced from the temporal. Thus, Climacus associates Plato's Socrates, with just such a view of temporality in general: as of vanishing significance, nothing more than an occasion for 'practicing dying and being dead' by recollecting the eternal forms. ${ }^{13}$

For Climacus, Christianity is, therefore, founded on a certain type of lived experience. Through 'the eyes of faith,' the believer comes to experience her own future as bound up with the historical moment of Jesus of Nazareth. It may, of course, be that a given believer's experience of this sort is dated many years after Christ. Within the lived experience, however, the believer is contemporary with Christ: Christ's moment in time manifests itself as decisive for the believer's own life-trajectory. This is what Climacus calls 'the autopsy of faith' in the etymological sense of seeing for oneself [autos 'self' + optos 'seen'] (Kierkegaard 1985, p. 70). Structurally, this account of 'the eyes of faith' ought to remind us of Ingeborg's glance of the eye. While these experiences are, of course, quite different in content, the way the Christian beholds Christ's life as a historical watershed, charged with significance for her own life, shares with Ingeborg's beholding of the sea this same structure: an experience of a temporal threshold, which disrupts the chronological flow of time and is primarily future-oriented in character. However, there is also this difference: for Ingeborg, the departure of Frithiof closes off an anticipated future; for the Christian believer, by contrast, the advent of Christ, the God-Man, opens up an unanticipated future - of eternal joy and peace. Again, in the terms of the New Testament writers, the foundational Christian experience is not merely of a temporal threshold but of the fullness of time. ${ }^{14}$

Much in Kierkegaard might well be described as working out the ways this foundational experience of the fullness of time is apt to transform the Christian's whole orientation toward temporality as such. Witness, for example, how he describes Christian love, in radical contradistinction to all our merely temporal loves. The latter, so long as they remain unrequited or in some other way unfulfilled, leave us restless and lovesick:

That an expectancy is essentially only temporal makes for restlessness in expectancy. Without restlessness time does not really exist. It does not exist for the animal, which is completely devoid of restlessness and the clock that tells the time cannot do so when the restlessness ceases ... But the one who loves, who abides, has an eternal expectancy, and this eternal element provides evenness in the restlessness, which, in time, does indeed oscillate between fulfillment and nonfulfillment but independently of time, inasmuch as the fulfillment is by

12 We can anticipate here the following worry: in religious contexts, the meaning of the term 'eternal' radically shifts from the sense in which we have so far introduced it, in connection with Ingeborg's perspective on her life-trajectory as a whole. This worry, likely to be felt by secular readers, raises issues too large to address here. My own view is that Kierkegaard's term 'eternal' [evig] is not ambiguous but rather expresses a conception in which a core idea of one's being granted a perspective from 'outside of time' is specified in different ways across secular and religious contexts. One way to capture a difference is the following. To describe Ingeborg, we need only the idea of a disruption of time from within, a break-down of the temporal flow, which affords a perspective on one's life as a whole. To describe the Christian experience of the eternal in time, in Christian terms, we need the idea of a disruption of time from without, from God. Kierkegaard's notion of the eternal is usefully situated in a context of post-Kantian philosophy in (Welchman 2016).

13 See (Kierkegaard 1985, p. 24ff); cf. Plato Phaedo 64a.

14 In a way that is informed by Kierkegaard's work, this theme is central in the writings of Paul Tillich. See for example (Tillich 1998, p. 32ff). 
no means made impossible because time is over-this one who loves does not wither away.

(Kierkegaard 1995, p. 313)

A careless reading of such passages might lead the reader into understanding them via old Peterson's world-weary opposition between eternity and time. Again, however, I submit that the truly Kierkegaardian figure in Ordet is instead Inger, whose upward glance in the midst of everyday kindnesses to others perhaps betokens just the kind of 'evenness in the restlessness' that he here associates with 'the eternal element' in Christian love.

Now, we have seen already how Ordet emblematizes different styles of a religious response to times of crisis. However, the ultimate crisis for its protagonists, as for the film's viewers, is the moment of Inger's (apparent) death. ('Apparent' because the door is left ajar that, as the reductionist-minded doctor can only surmise, there has been some medical mistake around the pronouncement of death.) Some viewers will no doubt feel cheated by how the film resolves this crisis. Douglas Messerli perhaps speaks for many.

Instinctively, I find something stagey about this ending, with a kind of deus ex machina intrusion that does not seem necessary given Dreyer's argument throughout for a religion of life. (Messerli 2012)

To be sure, it is compatible with this reaction to acknowledge the power of the film's ending as a metaphor. A metaphor for what? One possibility here is Kierkegaard's thought that the one who truly loves does not wither away. On this reading, Inger's resurrection is a symbol for the eternal character of the kind of love she typifies. Moreover, we might add that Johannes' parallel restoration to sanity could be seen as a symbol for genuine faith: where before he so identified with Christ's historical moment that he confused himself with Christ, now Johannes comes into the authentic experience of contemporaneity. ${ }^{15}$ My own suggestion, however, is that, more than a metaphor, what Dreyer offers in this film's divisive dénouement is a cinematic enactment of the very experience of the fullness of time. Given what we have seen of its attention to experiences of time as such, and especially to religious styles of response to times of crisis, this looks to be a perfectly fitting ambition for the film's ending. Yet could a film really do that? Could there be such a thing as a cinematic experience of the fullness of time? Is this really what we experience as film-watchers when we witness Inger's death-and then her, very bodily, resurrection?

In my view, these questions present the real problematic of Ordet's ending, not whether the film is licensed to its deux ex machina. To help broach them, I propose to turn again to Kierkegaard's work, this time to a text which approaches 'the eternal in time' in a straightforwardly aesthetic context-specifically, the theater.

\section{Inger after Inter et Inter}

A term in German for a mid-life crisis is 'Torschlusspanik', literally 'shut-door-panic': a feeling as of being on the wrong side of a closing gate. Now, just such an experience is what is at ostensibly at stake in a short, brilliant but often neglected piece published by Kierkegaard entitled, The Crisis and a Crisis in the Life of an Actress. ${ }^{16}$ Attributed to yet another fictional author-one 'Inter et Inter' - this essay

15 Another possible interpretation takes its cue from the film's opening credit which specifically references 'Kaj Munk's Ordet'. For the film's original Danish audience, Munk would have been known above all as a martyr for the resistance movement. (As a result of his opposition to the Nazis, Munk was arrested by the Gestapo on 4 January, 1944 and his corpse found in a ditch the following morning. He is commemorated as a martyr in the Lutheran Church's Calendar of Saints.) Against this background, it would not be implausible to see Inger's resurrection as a figurative call for national renewal. My thanks to the editor of this special edition of Religions for drawing to my attention this interpretative possibility. Without at all wishing to deny them, however, I leave aside here the more political dimensions of the film.

16 Kierkegaard's essay is ostensibly just about a particular crisis in the life of an envisaged actress. As is plausibly indicated by the contrast between the indefinite and the definite article in its title, however, Kierkegaard uses this particular crisis to think through a fundamental form of human experience of crisis quite generally. For further discussion, see (Watts 2017). 
invites us to entertain the following scenario. In her youth, a certain actress had reprised Shakespeare's Juliet to great public and critical acclaim. Ever since, she has enjoyed celebrity status and a close association in the public imagination with Juliet, as a sort of symbol of feminine vitality. But now she is, as they say, getting older. Her once idolizing public are beginning to pay lip-service to her looks and talent, perhaps even secretly relishing the spectacle of a fading star: 'a sneaky, uneasy, basically well-meaning but yet in its curiosity treasonable reflection is beginning to whisper that she is getting older' (Kierkegaard 1997, p. 318). Where does she go from here?

The real-world occasion for this theme was no doubt the celebrated return of Johannes Louise Heiberg to the stage in Copenhagen. To everyone's surprise, Mme Heiberg, now in her midlife, returned to reprise once again the part which had shot her to fame as a teenager-Shakespeare's Juliet. His interest in the whole scenario evidently turns on Inter et Inter's impression of there being something wondrous about such a return to Juliet, conceived as a response to the crisis he envisages. To be sure, he recognizes other possibilities. For one, our actress might instead reconcile herself to her own changing physicality by taking on only older roles (such as Juliet's nurse). ${ }^{17} \mathrm{He}$ emphasizes that this kind of continuity would be far more in line with the audience's expectations. Yet, for Inter et Inter, what makes this other scenario so wondrous-the one in which our actress responds to her midlife crisis by returning to Juliet—is the new possibilities he thinks it opens up for a superlative performance of Juliet, all the more exemplary than the one that made her reputation in the first place.

Why does Inter et Inter associate the prospect of a midlife reprisal of Juliet with new possibilities for aesthetic excellence? Part of his discussion runs as follows:

Time has asserted its rights. There is something that has become a thing of the past. But then, in turn, an ideality of recollection will vividly illuminate the whole performance, an incarnation that was not present even in those days of the first youthfulness. Only in recollection is there complete tranquility, and, therefore, the calm fire of the eternal, its imperishable glow ... This pure, calmed and rejuvenating recollecting, like an idealizing light, will transilluminate the whole performance, which in this illumination will be completely transparent.

(Kierkegaard 1997, p. 323)

What does this mean? Start with the idea of complete transparency. Inter et Inter supposes that, when she first reprised Juliet as a teenager, our actress' performance was less than perfectly transparent. That is, he surmises that there was within it something opaque and obscuring-with respect to the Idea of Juliet, conceived as an aesthetic idea that transcends any particular performance. Now, while he associates the idea of Juliet with a general idea of 'feminine youthfulness,' Inter et Inter also thinks that any adequate interpretation of this idea must somehow bear the weight of Juliet's 'intense complexity' (ibid., p. 321). He, therefore, surmises that, in her early reprisals of this role, the obscuring factor was the actress' own youthfulness and her particular inflection of femininity: in short, audiences were always liable to mistake the idea of Juliet for this striking teenager before them and, so liable to miss, for example, something of the depth and complexity that any truly adequate interpretation of this idea would need to bring out.

By returning to the role later in life, however, our actress can seize the new possibility of achieving just this kind of transparency in which the audience is enabled to see right through her performance, as it were, to the very idea of Juliet. Thanks to what time has taken away from her, there is no longer the inherent danger of the idea of Juliet being confused with the ephemeral qualities of her youthful self: the qualities of a young Claire Danes, say, or Mme Heiberg. In this way, our actress may even be seen to gain a kind victory over time, thanks, ironically, to what it has stolen from her. In this scenario,

17 On the contrast between these alternatives, as general responses to crises of personal and ethical identity, see (Watts 2017). 
it turns out that 'time has no power actually to take away: it is only a serving power that serves to make manifest' (ibid., p. 322).

What exactly is the audience supposed to see when a performance of Juliet is transparent with respect to the Idea of Juliet? (Compare: what is an audience supposed to hear when a particular performance of Beethoven's ninth, say, is transparent to its aesthetic Idea?) Inter et Inter's answer is given by his appeal in this context to the notions of recollection and the eternal. In a sense, no doubt, the audience sees nothing more than this particular performance-just as, in a sense, Ingeborg sees nothing more than the sea. However, in Inter et Inter's view, the audience's perception of a performance, when transparent to its aesthetic Idea, is temporally structured in a particular way. At one level, the audience's attention is just on what is going to happen next, as one scene leads to another. However, in the ideal case, they also experience the performance in a way that disrupts the temporal flow, transcending time and place as it recollects its aesthetic Idea.

From this, and for our purposes here, I think we can extrapolate the following two points. First, in a Kierkegaardian view, the theater can provide experiences in which performances in time are touched by the eternal. In the example just outlined, an audience experiences the idea of Juliet in a way that outstrips what they directly perceive in the performance, 'transilluminating' the performance as a whole. Although, for obvious historical reasons, Kierkegaard has nothing to say on the subject, there is arguably no reason to distinguish, in this regard, the theater from the cinema. ${ }^{18}$ Additionally, it is quite striking in this connection to note the words of one rapturous review in the immediate critical reception of Ordet in the Danish newspapers, 'A human experience of the highest value ... It is with elevation and rapture that one leaves it. A perfect work of art, not subject to time' (Drum and Drum 2000, p. 243).

Second, however, the type of experience that Inter et Inter associates with the theater is subtly but importantly different from the types we associated above with Ingeborg and with the foundational Christian experience of contemporaneity with Christ. This is the contrast between the essentially recollective, retrospective character of purely aesthetic experiences and the essentially futural, prospective character of existentially involved experiences of the moment qua temporal threshold. Ingeborg's gaze out to sea bears on her own future in a highly personal and involved way. Likewise, in the case of the believer's eyes of faith. Yet, for the audience of a theatrical performance, however ideally transparent, there is in Inter et Inter's description no such essential futurity to the experience: instead, as he puts it, in the very best performances, we enjoy an experience of 'complete tranquillity' and 'the calm fire of the eternal, its imperishable glow.'

About the ending of Ordet, then, we are still left with a question. Does Dreyer's film truly provide an experience of the fullness of time, given the essentially future-oriented character of such experiences? Or must any such attempt to make available this kind of experience at best collapse back into the calm glow of aesthetic recollection? From my own limited observations of audience reactions to this film, 'complete tranquility' is scarcely the phrase that would best describe them ('deeply unsettled' would be closer). One possibility, then, is that Ordet turns out, in this regard, to provide a critical perspective on Kierkegaard's view of the limits of the aesthetic. In the end, however, perhaps we should instead describe Dreyer's film in the way Kierkegaard described Shakespeare's Hamlet: as a masterpiece that, in the way it pushes its medium right up to the boundaries of the aesthetic, borders on the religious. ${ }^{19}$

Funding: This research has been supported by a grant from the UK Arts and Humanities Research Council for the project, 'The Ethics of Powerlessness: the Theological Virtues Today'.

18 Against this, attention might be drawn to the specifically ephemeral character of a theatrical performance in contrast to recorded film (I owe this point to Béatrice Han-Pile). As viewed by an audience at a time, however, the pictures of a motion film surely have their own specifically ephemeral character. Dreyer reflects on the relationship between film and theatre in (Wahl 2012, p. 149ff).

19 See (Kierkegaard 1988, p. 452ff). 
Acknowledgments: For helpful discussion, my thanks to John Gillies, Béatrice Han-Pile, Joshua Furnal and Robert Stern.

Conflicts of Interest: The author declares no conflict of interest.

\section{References}

Arestad, Sverre. 1954. Kaj Munk as a Dramatist. Scandinavian Studies 26: 157.

Blake, William. 2008. The Complete Poetry and Prose of William Blake. Edited by David V. Erdman. Berkeley: University of California Press.

Bordwell, David. 1981. The Films of Carl-Theodor Dreyer. Berkeley: University of California Press.

Borges, Jorge Luis. 2007. Labyrinths. New York: New Directions Publishing.

Buckser, Andrew. 1993. Communities of Faith: Sectarianism, Identity, and Social Change on a Danish Island. Berkeley: University of California Press.

Carlisle, Clare. 2016. Humble Courage: Kierkegaard on Abraham and Mary. Literature and Theology 30: $278-92$. [CrossRef]

Drum, Jean, and Dale D. Drum. 2000. My Only Great Passion: The Life and Films of Carl Th. Dreyer. London: Scarecrow Press.

Garff, Joakim. 2000. Søren Kierkegaard: A Biography. Translated by Bruce H. Kirmmse. Oxford: Princeton University Press.

Heidegger, Martin. 1962. Being and Time. Translated by John Macquarrie, and Edward Robinson. Oxford: Blackwell.

Kierkegaard, Søren. 1981. The Concept of Anxiety. Translated by Reidar Thompte. Princeton: Princeton University Press.

Kierkegaard, Søren. 1985. Philosophical Fragments and Johannes Climacus. Translated by Edna H. Hong, and Howard V. Hong. Princeton: Princeton University Press.

Kierkegaard, Søren. 1987. Either/Or Vol. I. Translated by Howard V. Hong, and Edna H. Hong. Princeton: Princeton University Press.

Kierkegaard, Søren. 1988. Stages on Life's Way. Translated by Howard V. Hong, and Edna H. Hong. Princeton: Princeton University Press.

Kierkegaard, Søren. 1991. Practice in Christianity. Translated by Howard V. Hong, and Edna H. Hong. Princeton: Princeton University Press.

Kierkegaard, Søren. 1992. Concluding Unscientific Postscript to the Philosophical Fragments. Translated by Howard V. Hong, and Edna H. Hong. Princeton: Princeton University Press, vols. I and II.

Kierkegaard, Søren. 1995. Works of Love. Translated by Howard V. Hong, and Edna H. Hong. Princeton: Princeton University Press.

Kierkegaard, Søren. 1997. Christian Discourses and The Crisis and a Crisis in the Life of an Actress. Translated by Howard V. Hong, and Edna H. Hong. Princeton: Princeton University Press.

Kierkegaard, Søren. 1998. The Point of View. Translated by Howard V. Hong, and Edna H. Hong. Princeton: Princeton University Press.

Lear, Jonathan. 2014. A Case for Irony. Harvard: Harvard University Press.

McTaggart, John M. E. 1908. The Unreality of Time. Mind 17: 457-74. [CrossRef]

Messerli, Douglas. 2012. Faith in Death, Faith in Life. World Cinema Review (Blog). Available online: http: / /internationalcinemareview.blogspot.com/2012/08/carl-theodor-dreyer-ordet-word.html (accessed on 28 August 2012).

Owen, Gareth S., Fabian Freyenhagen, Matthew Hotopf, and Wayne Martin. 2015. Temporal inabilities and decision-making capacity in depression. Phenomenology and the Cognitive Sciences 14: 163-82. [CrossRef]

Pattison, George. 2002. Kierkegaard, Religion and the Nineteenth-Century Crisis of Culture. Cambridge: Cambridge University Press.

Rosenbaum, Jonathan. 2010. Goodbye Cinema, Hello Cinephilia: Film Culture in Transition. London: University of Chicago Press.

Strawson, Galen. 2004. Against Narrativity. Ratio 17: 428-52. [CrossRef]

Tillich, Paul. 1998. Kairos. In The Protestant Era. Translated by James Luther Adams. Chicago: Chicago University Press. 
Wahl, Jean. 2012. Carl Theodor Dreyer and Ordet: My Summer with the Danish Filmmaker. Lexington: University of Kentucky.

Watts, Daniel. 2017. Kierkegaard, Repetition and Ethical Constancy. Philosophical Investigations 40: 414-39. [CrossRef]

Welchman, Alistair. 2016. Eternity in Kant and Post-Kantian European Thought. In Eternity: A History. Edited by Yitzhak Melamed. Oxford: Oxford University Press, pp. 179-225.

Ziolkowski, Eric. 2011. The Literary Kierkegaard. Evanston: Northwestern University Press.

(C) 2019 by the author. Licensee MDPI, Basel, Switzerland. This article is an open access article distributed under the terms and conditions of the Creative Commons Attribution (CC BY) license (http:/ / creativecommons.org/licenses/by/4.0/). 